$-74-(324)$

-7.7 mg で三宅 ${ }^{(8)}$ 等の唱える日本人成年女子の平均 傾 $6.3 \mathrm{mg}-12.5 \mathrm{mg}$ 大野 ${ }^{19}$ の $5.0 \mathrm{mg}-16.0 \mathrm{mg}$ に比 較して可なり低い値を示しているが，これにアスピリ ン, サリチラミン, コーチ・゙ン等を投与すると何れの 場合も著明とは言い難いが軽度の増加の傾向を示する の〉如くである。三者の間に程度の差は認め難く, 且 何れもその増加は正常值の範囲内に止ることは屋形 ${ }^{12}$ の場合と同样である。

17-K の増墨と尿量との関係については尿墨の少い ときには含有量が概して高く, 增量に伴つて尿量の多 くなることは楒められず関 ${ }^{20)}$ の所見に一致している。

好酸球数は三者何れの場合す㽖摇甚たしく正常の日 內変動と見る可く意義を認め難い。

この患者は治擔前から中等度の貸血があり，血沈值

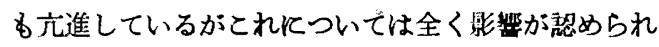
ない。

血球数，血色素含有量についても同样全く変化が認 められない。

自覚症状を主とする治撞効果次ついては何れるある 程度の自発痛及び连動痛の緩解を訴え，これに伴つて 過動能力の恢復が琶められたが，その程度については サリチル酸剛の中ではアスピリンがや〉勝れた結果を 示したが向治療期間中に於ても効果の動摇があつた。 コーテゾンはこの二者に比較して効果の発現早く且比 較的動摇が少かつたが治療中止後再び治㞠前の状態汇 復すっことは何れる同様であつた。

結語

多発性関節リウマチの一例にアスピリン，サリチラ
日医大誌第 22 巻第 4 号 (1955)

ミン，コーチ・゙ンを交互に投与して臨床症状，尿中 17-K 量流血中好酸球数等を測定して比較した結果ほ ๖同様の結果を得て三者の間に著明を差な認め得なか つた。

稿を終ると当り御指望御校閲並に御助言を賜つた赤 木教授西村教授及び能丞院最火感謝の意を表する。

\section{引用文献}

1)沖中, 西川：内分泌のつどい, 第 3 輯, 742 (1952)

2) 阔藤：内分泌のつどい，第 1 輯， 160 (1952)

3) Crevald, Kuipers : Ned. Tijsch, generesk, 94. 2175 (1950) ; British Abstract, 53, April による

4) Pempen : 同誌 94, 2170 (1950)

5) Dingemanse, Huis : 同誌, 94, 2182 (1950)

6) 屋形: 新㴙医会誌, 67. 2(1953)

7) 矢野：治療，9，6(1952)

8) 屋形：日内科会誌，41，445（1951）

9) Cauwenberger : Lancet, 261, 374 (1951)

10) Hetzel, Hine : Lancet, 261, 94 (1951)

11) 屋形：日本臨床, 10, 1040 (1951)

12) Beltolani, Lorenzini; Bonati : Lancet, 260. 54 (1951)

13) Meade, Smith : Lancet, 260, 773 (1951)

14）青木：日楽理誌, 47, 124 (1950)

15) Roskam, Cauwenbeger, Mutsers : Lancet, 261, 375 (1951)

17) Drecter: J. clinical Endocrinology, 7, 12 (1947)

18）三宅：臨床，4，8（1951）

19）大野：内分泌のつどい，第 3 輯，621 (1953)

20）関：内分泌のつどい，第 3 輯，645 (1953)

\title{
Grawitz 氏腫瘍と誤診せられた
}

Hodgkin 氏病の一例

\author{
日本医科大学解剖学教室（主任 横尾安夫教投） \\ 澉赤赤十字病院 \\ 田中庣夫 • 小林份 - 両角節 \\ Yasuo Tanaka Takashi Kobayashi Setu Morozumi
}

緒 言

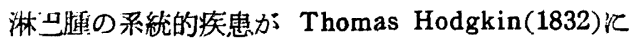
より，英国で初めて報告されWilks(1856)が此を Ho. dgkin 氏病と命名したのが此 Hodgkin 氏病のはじま
りである。併しながら当時は本疾患の中には結核性淋 巴腺䏦や淋巴性白血病をる含まれており，更に淋巴肉 腫症や細網肉腄との区別がされていなかつた。最近幾 多の研究者によつて此等の疾覞と臨牃的に又病理組織 
学的に，或は血腹所見の上から区別され Hodgkin 氏 病の全貌が明らか㶤された，かかる Hodgkin 氏病は

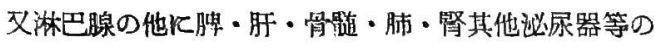
股器を犯すと云はれているが，偶々大きな腎腄演のた

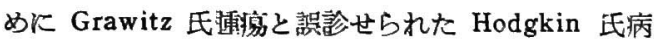
の一例を経蝤したので報告する。

\section{患者： : 男 40 歳 会社員}

家族歴・既往症：共侍記すべきものはなく, 結 核, 悪生婳瘍も認めない。

現病歴: 2 年前より時々腰痛を訴光, 神経浦と云わ れていた。昭和 29 年 3 月上旬上り腰痛堌强し医撩鐵 療を受けたが軽纼せず，4月上旬より下肢に浮㬸が現 われ，急生腎炎と猃断された，浮腫は濑次增加し 4 月 下旬には全身に及んだ。呼吸促迫: 胸内苦閔あり腰痛 激しく歩行不能となつた。

現应: 昭和 29 年 5 月 6 日初猃, 体格栄養共飞住良 体温 $36.5^{\circ}$ 脈膊頻数梢々微弱にして顔貌浮腄状・苦 閍状を呈す。呼吸倨迫し概权半起坐の姿勢をとる，左 鎖盈上㸗に掫指頭大の比較的柔い淋巴腺腫脹を触れる

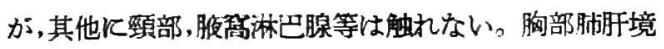
界稍々上䒜し, 心潈音界は稍々左側犯偏す。心音・呼吸 音汇異常がない。腹部稍々膨満し, 正中線汇て肝を 2 横

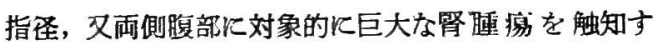
る。腫瑒は棈円形飞て直立し, 両助骨弓下飞存在し, 表面平滑不動生にして大きさは右は右乳線上 4 横指 徍, 左は左乳線上 3 横指径触知与る。又腹水眝溜の症 状を認める。腹壁静脈の怒張はない。下肢浮腫著明, 睖蓋硉反射は䅌々微弱である。尿量は約 50ccである。

\section{諸検查}

（1）尿：黄褐色透明にして, 比重 1025, 蛋白弱 陽性, ピリルビン・ウロビリン・ウロビリノーゲン共 飞陰珄, 沈渣は赤血球, 白血球を認め, 腎上皮紐胞を も認めるる, 円柱及腫揚細胞は認めない。

（2）血腹: 赤血球 383 万・白血球 6200 -血色素 （ザーリ一氏法）70\%・白血球の百分率は好塩基球 $0.5 \%$. 好酸球 $3.5 \%$ - メ夕好中球 0 - 桿状核好中球 4.5\% - 分核好中球 $57.0 \%$ - 淋巴球 $29.0 \%$ - 単球 4.0 多 - 形質球 $1.5 \%$ 飞して, 其他有核赤血球 $(-)$ ・ 異型赤血球 $(-)$ - 大小不同赤血球 $(+)$ 多染色赤血 球

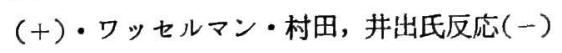

(3) レ線検查 :

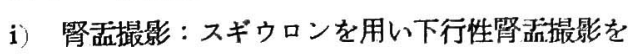

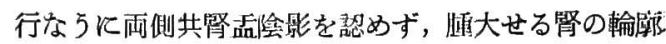
を示す淡い檷慢性の陰影を認める。

ii) 胸部撮影：肺・肺門淋巴腺・及心墭陰影は特汇 異常を認め宋い。

（4）其他の検查：ツベルタリン皮内反応陽性血沈 1 時間 $88 \mathrm{~mm}, 2$ 時間 $105 \mathrm{~mm}$, 松原氏婳反応陰性,

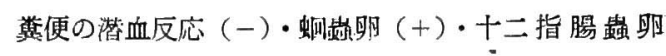
$(-)$

\section{診断: Grawitz 氏腫泇}

其後の経過：5月 6 日入院以後平熱炕経過する 的食 思不振・幅気・水様便 1 日 $4 \sim 5$ 回山り。尿量一日平均 $200 \mathrm{cc}$ 前後次して, 浮蕾は遂次增加し，5月 17 日心 歲秝㾇にて突然死亡した。

肉眼的所見： -

i ) 両側腎は上半尰㴦栐肥大あり (図参照) 色は灰 白黄裀色を呈し，腎歪腔搪大し実質内に数ヶの炏白色 結節を認める。

ii）大動脈周囲では後腹脱淤 巴腺の腫大並に腺塊形成を言

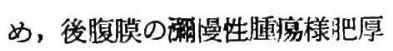
を認める。

iii）副腎 : 右は副㹂の正常構 造を認めず, 左副腎は萎縮し粟 粒大万至小豆大の $2 \sim 3$ ケの灰

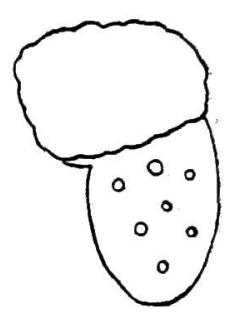
白色結節を垫める。

iv）左鎖骨上墭の沜凅大の淋?節腫脹

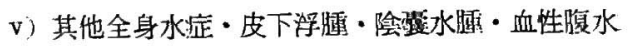

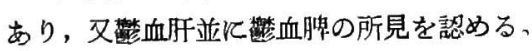

顕微䍌的所見 :

図1 ステルンベルグ氏型巨細胞少数認める 淋巴腺（强拡大）

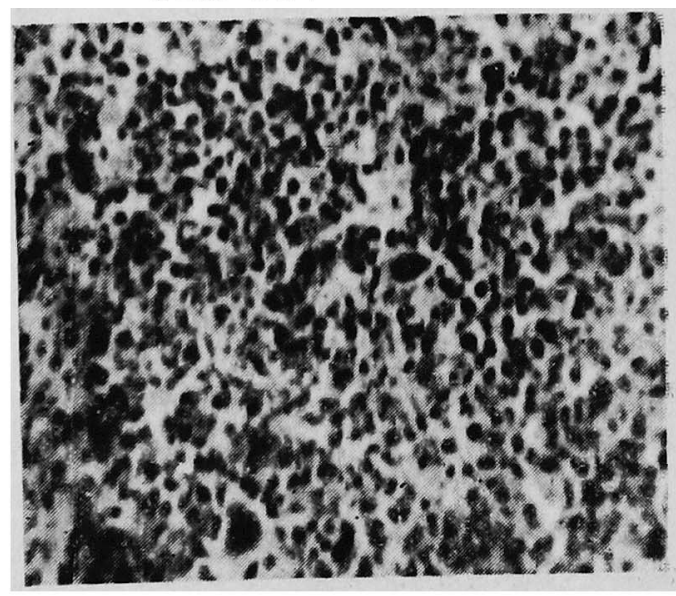




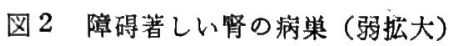

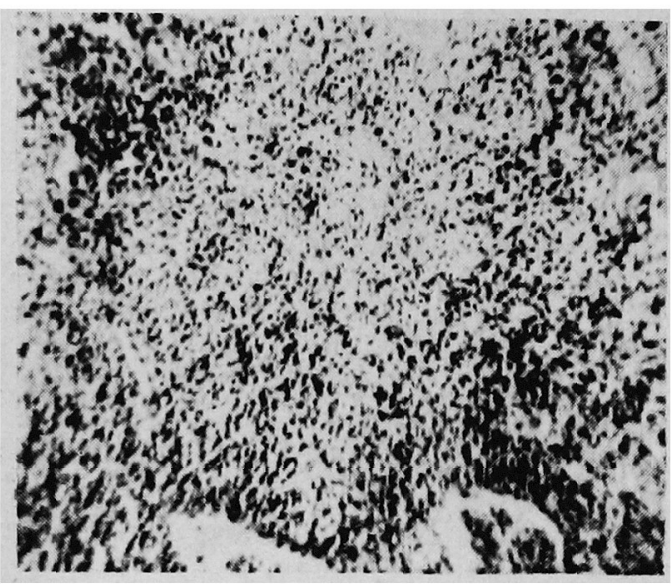

淋巴腺・腎は特有な内芽腫を形成している。細網内 皮細胞・結合䋐維細胞の增殖著しく，類上皮細胞・淋 巴球・形質細胞 - 好酸球等の浸溜 - 增殖並に少数のス テルンベルグ氏型巨細胞を認め，一部壊死雀・䋐維 化を認めてホドキン氏病の組織像に最もよく似た像を 呈している。(図1・図2)

\section{考案}

Hodgkin 氏病江近年組織学的研究が行われるよう そなつてから遂年増加の傾向にある。守屋によると米 国では人口 10 万亿対して 0.5 から最近 2.5 K上星し ている，但米国の Hodgkin 氏病中飞細網肉埂が含 まれてょり，我国のように紐網肉腫がよく研究されて わる所では Hodgkin 氏病は少ないと北村は述べてい るので, 米国はど多くはないと思われるが日本でも 最近は Hodgkin 氏病を肉芽種よりも細絧肉堙の 1 型 と見る傾向が多くなつてるる。男子は女子より慛㭧率 が高く，北村は 60〜 70\% が男子であると云い，宫 地・守屋は男子は女子の二倍の罪重率であると云5。 年龄的には老人，小児には比較的少なく，中年者行多 いと云うが，本例でる男子で年齡は 40 歳であるので 此に相当している。

病原体 : 本疾患の本態就ては炎症説, 腫㿋説, 両 者の中間説及新陳代謝異常説等あり。現在決定的なる のはないが，炎选説が最子有力のよ5である。炎症説 の中には古くは結核に関係ありとするすのから Virus 或は Brucella 菌・ヂフテリー類似菌・抗酸菌等によ るものなりと数多の学説がある。本疾患の本態が不明 であるので此等の菌の侵入口す决定出来ないが,口腔・ 明燋又は胃腸・䎵尿器・骨随等汒之を求める人がある。
症状：宮地は Symmers の本症のおこり方を次の 様に挙げている。

1）別に症状を訴えないるの（時に淋已腺の肥大と 皮原の瘙痒感を伴うのみ)。

2）淋巴腺がはれて其等てよる圧迫症状を訴少る。

3）自覚症状・圧迫症状がなく急に淋巴腺が大きく なつて, 圧迫症状と共に数週・数ケ月で倒れる。

此によると本例では 2) に相当し後腹膛淋巴腺腫脹 の為神経を圧迫し碩固な腰痛を惹起したものと考え られる。

淋巴腺の腆脹就ては本例では鎖骨上枀の淋巴腺が

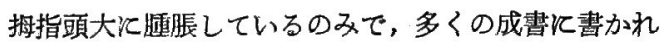
ている様汇, 頸部淋巴腺が最す早く且つ強く尰大する とは云えなかつた。併し剖見により後腹脱淋巴腺の腫 大を認めるが，近年腹胫淋巴腺の強く犯されている報 告が多く, 此が Hodgkin 氏病の侵入口が胃腸である と主腲する㙕拠次つている。又淋巴腺は頸部から綻 隔膜・腋简・腸間膜・後腹膜・鼠蹊淋巴腺と apicocaudal に拡がるすのとされているが, 後腹脱や闻蹊 淋巴腺のみが腫脹している事るあると北村恃述へ，又 Boyd の「Hodgkin 氏病の際は非連続的に犯すのが特 徴である」と云 5 言を挙げているが，本例では鎖骨上 啁と後腹膜淋巴腺腫大を認めたに過ぎない。

淋已腺の他江肝腫は $75 \%$ 。脾腫は $50 \%$ にみられる と云うが,本例では肝,督を触知し脾は触れなかつた。 熱型は Pel Ebstein 型（有熱期と無熱期が交替洦 はれる)と云はれるが，本例では平熱経過した。文 淋巴腺や浩血㩔器の著しい腫脹の為, 圧迫症状が顕著 となり，全身汇浮腫を見ると至ると云われるが，本例 の如く腎が著しく犯され尿量が少くないので，圧迫症 状がなくとも浮嗹が現われるのは当然であろ5。又圧

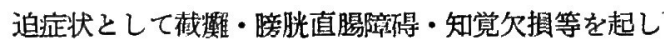
て来ると云われるが, 此事は見られなかつた。

血液所見は特有な変化はない。北村は「赤血球は減 少し白血球增加症をみる事多く，白血球減少を示寸事 は比較的少ない。淋巴琫は絶対数に於て稍々減少し， 好エオヂン細胞は多くは著しい増加を示すが，時には 之を欠く事がある」と述へているが，本例では赤血球 の減少, 淋巴球の稍々増加以外淿は著しい変化は見ら れなかつた。

肉眼的所見として多くの研究者は脾が斑岩脾 (Porphyrmilz) である事が本疾㭧の重要所見として挙げ ている。即肉眼的に大小の結節を多数形成し，その割 面は灰白色又は黄色乃至は褐色を带びていると云われ 
るが，本例では篮脾の所見をみるだけであつた。肝 䑏子被膜の直下飞結節を形成すると云われるが，矢張 り胉同様领血肝の所見をみるのみであつた。淋巴腺や 肝，脾の他飞腎・肺・㕃桃腺 - 甲状腺 - 副腎・泌尿 器・皮锯等を犯すと云われるが，本例では腎は著しく 睡大し，その為 Grawitz 氏腄痬と誤診せしめた。又 副腎も犯され，何れも灰白色の結節を認めた。

組践学的所見 : 小林は組織像の特長は其多栏性にあ り試験的切除の小片を幾度か検查して, 其度毎に異つ た所見を呈すると述べているが，定型的組織像として 病期を分けて Braitenbergの分類を挙げている。即

I 初期 (非特異性增生, 非特異性笭出性炎症一 洞カタル)

II 極期（特異性内芽形成）

III 末期（堙死・赦維化一一硝子化）

初期任出性济巴腺炎の像であり，特異性肉芽形成 は淋巴勫胞の他，淋巴管内皮細胞，細網細胞（類上皮 細胞)䋐維芽細胞が増生し、ステルンベルク型の多核巨 態細胞す出現し，更にエオデン㗪好性白血球や形質細 胞も加はる。此が肉芽組裁であつて, 其為淋巴腺は著 しく尰大して来る。末期ては此肉芽絕織は変性及堎死 を起し，他方組織の織維化が起り徐々に進行して行

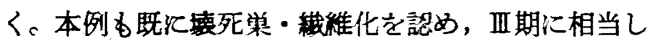
ている。又此の所見により淋巴肉腄, 紐網肉腄・淋巴 性白血病等と組織学的て区別されるが細網肉腫の多形 細胞型との区別はむずかしい。

経過及予後 : 守屋は (1) 緩漫省経過な示し，12１4
年す比較的状隼がよく経過するものと（2）10週間位で 死亡する急性型と，(3) 此両者の中間型で 7 ケ月〜12 ケ月位の経過で死亡するものとの三大別をしている が, 本例では初発症状より約 2 ケ年, 浮腫が発現して から約 6 週間で死亡している。又䛲胛・発熱・棒疹・ 淋巴腺胛䛜脹が著明なるの, 更飞腹腔淋巴腺腫脹が著し いもの, 胃腸症状の強いもの, 赤血球漸減するもの, 病初から血泌促進, 体重減少の著明のすのは予後は悪 いと述べているが，本例では浮蕾の存在は死期を著し く早めている。

$$
\text { 結言 }
$$

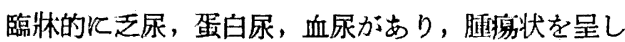

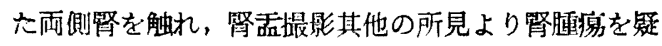
いGrawitz 氏腫激と診断したが，剖見とより両側腎 を広籍囲彷犯した Hodgkin 氏病なる事を知つた。入 院後間もなく死亡したが，早期に淋巴腺の試験的切除 を行つてX線治療や Nitrogen mustard 等の治療を 行5べきであつた。

擱筆飞当つて本学病理学教室木村哲二教授の御校閲 を深谢します。(本論文の要旨は昭和 29 年 10 月 31 日 内科学会信越地方会に報告した）

$$
\text { 文献 }
$$

1) 北村四郎：新潟医誌，64年 (10) 649 (1950)

2) 宮地 徹他：日本臨㸛，6，7 (1948)

3）小林忠義 : 慶応医学, 27, (1) 1 (1950)

4）守屋邦男：日本医事新報，1326 號（1949）

5）高木八郎他：日本血液誌，14，(4)230(1951)

\section{大腿骨頭に於ける所謂骨端炎の \\ 興味ある一例}

日本医科大学整形外科学教空（主任 高本慧次教授）

三原鏡

Akira Mihara

（本諭文の要旨は第 197 回整形外科集談会で発表し た)

$$
\text { 緒言 }
$$

Joeck は 1937 年に「おそらく骨病理学の部門に於 て，この無摩性骨壊死疾患の概念のるとに一括された る疾患程多数のアルバイトと研究を必要とした項目は
他にはないであるう」とのべた。ことほど左様にこの 疾患沈多数の業績が見られる。にも沏らずその病理 発生に関しては諸説粉々として,「外科学と病理学の 謎」なる語さえる見られている。斯くの如く混伅とし た中にあつて名倉氏は, 実験的に骨端損賃の修復に際 し軟骨仮骨の形成と軟骨内化骨の起ることを証明する 